\title{
BRIEF ECONOMIC ANALYSIS AND COMPARISON OF TURKISH AIRLINES, LUFTHANSA GROUP, AIR FRANCE · KLM
}

The paper described brief economic analysis and comparison of Turkish Airlines, Lufthansa Group and Air France KLM. Throughout the economic and commercial development and with disappearance of boundaries between countries is rapidly changing air transport. The transportation and logistics investments and competition between companies and states rapidly increased. Thus, transportation modes developed and changed rapidly as a natural response to development itself. In the paper, we will practice the comparison of two major companies of European Air Freight: Turkish Airlines and Lufthansa.

\section{INTRODUCTION}

Throughout the economic and commercial development and with disappearance of boundaries between countries, transportation and logistics investments and competition between companies and states rapidly increased. Thus, transportation modes developed and changed rapidly as a natural response to development itself. As many years' sea and road transportation headed the international transportation, nowadays speed and safety for transportation started to be prominent fact. It opened a way to air transportation to have a chair for itself through logistics sector. Besides, all other facts such as economical diffusion and cultural evolution, people started to need a new life trend and speed be-come fundamental of life. [3]

Here in this case, beyond the economical attitudes, we will practice the comparison of two major companies of European Air Transport: Turkish Airlines and Lufthansa.[5]

\section{CURRENT SITUATION OF TURKISH AIRLINES AND LUFTHANSA IN EUROPEAN MARKET}

As Lufthansa Airlines head the European Air Transport hub position, unless Turkish Airlines becomes the hub be-tween Europe, Asia and Africa with its central position. But beside, that two company can feed each other by alliance partnership. Frankly say, the situation is most likely "competition with set-up". Here it means, they try to cover their selves from the harm could cause by each other and also try to be "giants of sector". But meanwhile, either the central positions of companies or the political moves, both of companies invest (and can invest) massive money on service quality and base infrastructure. Through last six years, Turkish Airlines is one step further than Lufthansa and Air France - KLM partnership as well. According to Global Market Share Trends for last fifteen years (Table 1), Turkish Airlines has an increasing share trend in regard of the other companies and especially for Europe section, against Lufthansa. Even though Lufthansa has the more share of global market, Turkish Airlines' trend is significantly mortal for Lufthansa. [1]

During Lufthansa try to keep the connections through Europe and overseas like America, Turkish Airlines goes with the wind of its position and opens new connections through Africa. We can see the most significant move of Turkish Airlines with the project of new airport terminal in the north side of İstanbul. [3]

Tab. 1 Provided Connection Rates [9]

\begin{tabular}{|l|l|}
\hline Europe to World & \\
\hline Turkish Airlines & 20,096 \\
\hline British Airlines & 10,710 \\
\hline Lufthansa & 8,658 \\
\hline Middle East to World & \\
\hline Turkish Airlines & 8,534 \\
\hline Qatar Airways & 3,132 \\
\hline British Airways & 2,178 \\
\hline Africa to World & \\
\hline Turkish Airlines & 11,376 \\
\hline Air France & 4,488 \\
\hline British Airways & 3,264 \\
\hline
\end{tabular}

With new airport terminal Turkish Airlines would require the more connections like the shares of Lufthansa through Europe. While Africa and Europe connections feed the Turkish Airlines, it decreases shares of Lufthansa. And even more, Turkish Airlines require more. As we can see (Table 2), current connections are already in advantage of Turkish Airlines.

Lufthansa has massive connection with consolidations and sub-companies. It is also reliable strategy as we can see their network wealth. It is also a different way to enrich its network quality and provide more assets to run operations with developing them. As an example, Lufthansa has the shareholding position of 10 different companies and groups which are significant for Europe Air Transport and also six service providers. [2] 
Tab. 2 Global Market Shares (2002 - 2016) [9]

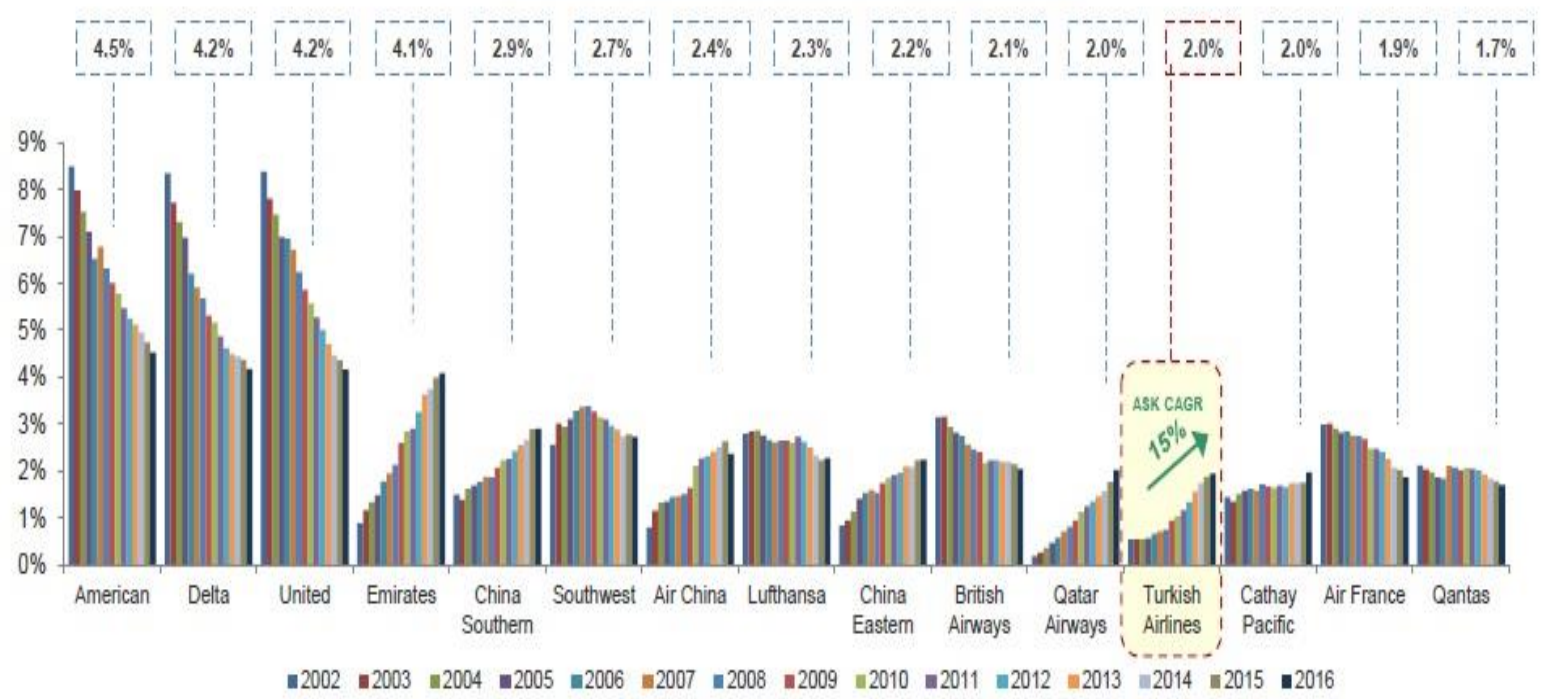

\section{METHODOLOGY OF CASE}

In this case we will examine the financial reports of both companies and practice their future economical movements through their investments. According to IATA it is not allowed to take government support but these companies are both half-governmental and so on their analyses must include also these supports in latent way. Anyway the main point of choosing that method is its clarity and precision. As mentioned before, government companies have many support from governments and also has many advertisementlike promotion works and it makes the analysis less certain. The numbers are more reliable to compare all other data. [4]

Through that type of analysis, there is no more figures that clearly shows us the current situation and future plans. Companies also would like to protect their main data and sustain their politics hidden. Thus analysis and practices must stick into data that given by companies and rigorous examination of papers and so on. [5]

\section{ECONOMIC ANALYSIS AND COMPARISON OF TURK- ISH AIRLINES AND LUFTHANSA}

Analyzing two companies according to financial reports shows us that Lufthansa has a massive power with its Lufthansa Group partnerships. Group reports are further than Turkish Airlines and also revenue between two participants of comparison is a giant gap. As mentioned before, this strategy is significant for success of Lufthansa Group and through reports it seems like it works. Also "purchasing the partnership" policy strengthen the basement of Lufthansa's futuristic plans.

Nevertheless, Turkish Airlines still stand alone against Lufthansa Group and furthermore it develops itself with a neverending-like growing process. While Lufthansa keeps purchasing companies and creating service providers, Turkish Airlines also strengthens its hub basis like solving the problem with domestic transportation and increasing the domestic destination plan to maximum. Besides, they focus on developing main hubs to make more convenient for international hub positioning. About this topic we can mention about new airport terminal at the north side of İstanbul, which is planning to be world's 5th biggest airport terminal. Also with connection of new airport and Ankara Esenboga Airport's to road and railway transportation indicates that they have goals about transportation.

We can see detailed comparison below with Fig. 1 to Fig. 6 .

\section{Number of Destinations}

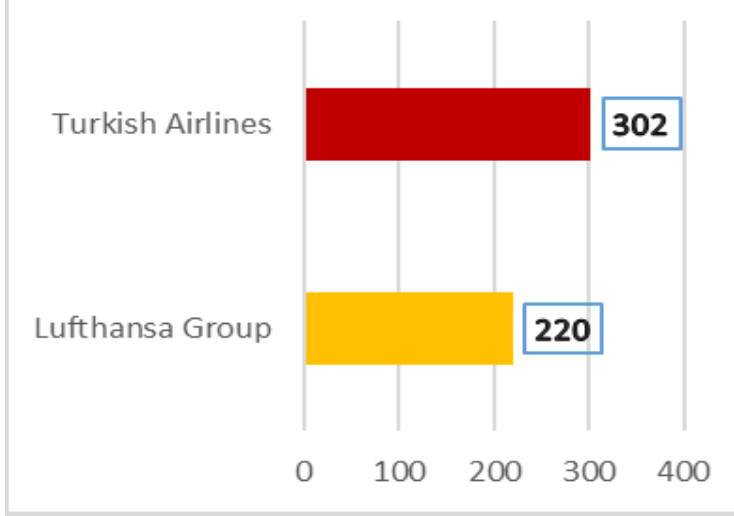

\section{Number of Destinations}



- Lufthansa Group - Air France

Fig. 1. Destination Comparison [10][11] 
Tab. 3 Network activity of Air France [10]

\begin{tabular}{|c|c|c|c|c|c|c|c|c|c|c|}
\hline & \multicolumn{2}{|c|}{$\begin{array}{l}\text { Capacity in ASK } \\
\text { (in million) }\end{array}$} & \multicolumn{2}{|c|}{$\begin{array}{l}\text { Traffic in RPK } \\
\text { (in million) }\end{array}$} & \multicolumn{2}{|c|}{$\begin{array}{l}\text { Load factor } \\
\quad \text { (in \%) }\end{array}$} & \multicolumn{2}{|c|}{$\begin{array}{l}\text { Number of pas- } \\
\text { sengers } \\
\text { (in million) }\end{array}$} & \multicolumn{2}{|c|}{$\begin{array}{l}\text { Scheduled passen } \\
\text { ger revenues (in } € \\
\text { million) }\end{array}$} \\
\hline & 2017 & 2016 & 2017 & 2016 & 2017 & 2016 & 2017 & 2016 & 2017 & 2016 \\
\hline Long-hual & 110,868 & 107,756 & 96,730 & 92,373 & 86.98 & 85.7 & 12,872 & 12,324 & 6,250 & 5,972 \\
\hline North America & 30,493 & 28,997 & 26,782 & 25,176 & 87.8 & 86.9 & 3,747 & 3,525 & 1,906 & 1,830 \\
\hline Latin America & 16,324 & 16,670 & 14,599 & 14,513 & 89.4 & 87.1 & 1,524 & 1,513 & 827 & 764 \\
\hline Asia and Pacific & 29,676 & 29,051 & 26,537 & 25,003 & 89.4 & 86.1 & 3,027 & 2,873 & 1,552 & 1,426 \\
\hline $\begin{array}{l}\text { Arica and Middle- } \\
\text { East }\end{array}$ & 18,777 & 18,083 & 15,166 & 14,560 & 80.8 & 80.5 & 2,705 & 2,619 & 1,225 & 1,209 \\
\hline $\begin{array}{l}\text { Caribbean and Indian } \\
\text { Ocean }\end{array}$ & 15,598 & 14,955 & 13,645 & 13,121 & 87.5 & 87.7 & 1,870 & 7,794 & 740 & 743 \\
\hline $\begin{array}{ll}\text { Short and } \\
\text { hual }\end{array}$ & 27,934 & 26,887 & 22,646 & 21,537 & 81.1 & 80.1 & 27,462 & 26,300 & 3,149 & 3,031 \\
\hline Total & 138,802 & 134,643 & 119,375 & 113,910 & 86.0 & 84.6 & 40,333 & 38,624 & 9,399 & 9,003 \\
\hline
\end{tabular}

With Figure 1 we can see that Turkish Airlines is a step further than Lufthansa Group. It is due to their efficient position between Europe, Asia and Africa. And this figure also shows us how they still can compete against Lufthansa Group and Sky Team partnership. This destination wideness also caused by Star Alliance membership of Lufthansa Group, but if we consider that both of them are member of the Alliance, it doesn't change and comparison fact.

Also Air France has a separate competition with Lufthansa. It effects Lufthansa Group and Turkish Airlines competition as well. The way it effects is creating a new destination competition through long-haul flights like North and South America especially. Lufthansa Group has great power to hand the European and America connection market but also Air France is taking place in that market especially with KLM partnership.

In Table 3 we can see how Air France - KLM group has place in long-haul transportation market compared to their short-haul flight activities. It's their main focus to have most effective share from aviation market because they know that they cannot have effective marge from only European market.

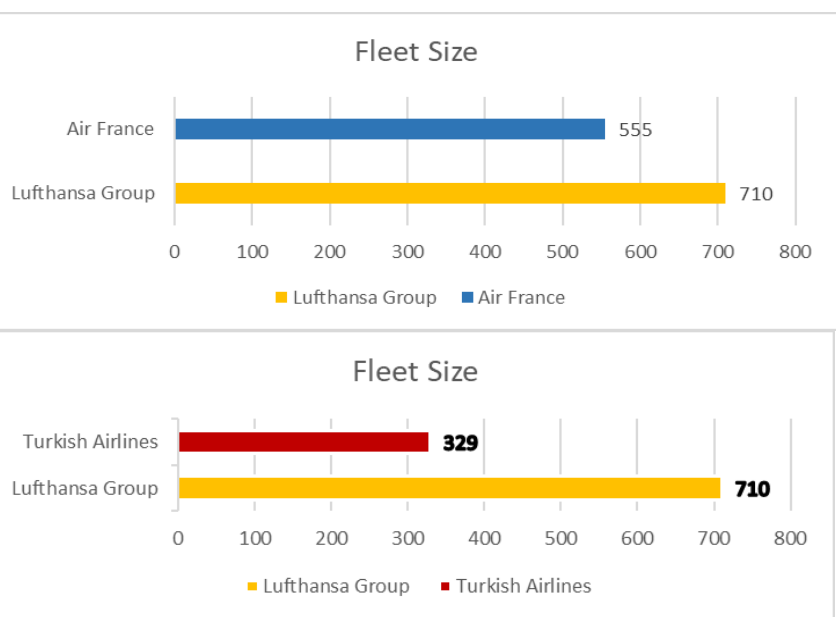

Fig. 2 Fleet sizes [10][11]

Fleet size of both companies (Turkish Airlines - Lufthansa Group) is well extended to provide that much destinations and have an efficient and sufficient service even through extraordinary situations. But must also mention with comparison, Turkish Airlines has that big fleet alone but Lufthansa has the other group members too like Swiss Airlines, Austrian Airlines, Brussel Airlines, Euro Wings, German Wings. With considering that much group partnership, those number is quite normal for Lufthansa Group. And if we compare destination points and that big fleet size, we can say that Lufthansa Group has better service background and more intense service network.

If we consider Air France - KLM Group as competitive of longhaul flights as we did before, we can see that they are not much effective about the competition between fleet sizes compared to Lufthansa Group. And also if we consider as Lufthansa Group is the titan of the market (in their main activity area - long-haul flights), they deserve their position with that effective and big fleet. Anyway their fleet is older compared to others, they have the power of that supported by two fundamental facts: destination and fleet size that feed each other.

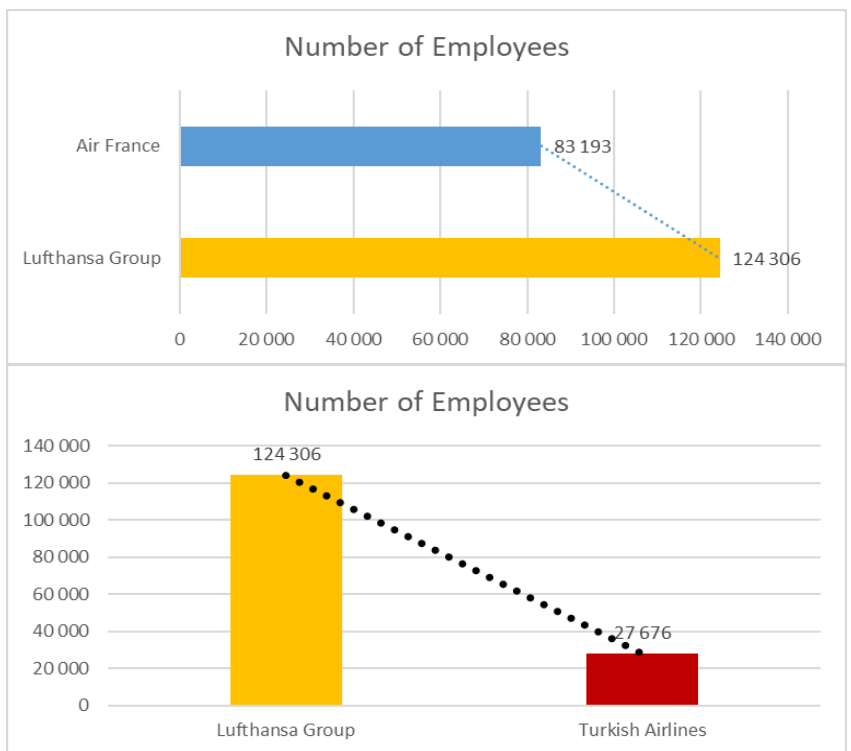

Fig. 3 Number of Employees [10][11]

As seen in Figure 3, there is a massive gap between employee numbers of two companies. It also caused by Lufthansa Group. Because Lufthansa Group has crowded number of members and also their headquarters are in different countries, Lufthansa needs more employees to fulfill whole operations. In a way it is necessary for Lufthansa Group but in the other hand it causes more staff expenses. Turkish Airlines is lucky in that comparison. They just have one headquarter and operates densely in one country. It helps them to save hundred-thousands of staff expenses compared to 
Lufthansa Group. And it is not a small amount according to new age's economical and managerial politics. If we consider that many companies try to decrease staff expenses, Lufthansa might have problem with that, if they not grow more and more.

From the second part of Figure 3 we can see that Lufthansa Group and Air France - KLM Group don't have quite big gap like Turkish Airlines - Lufthansa Group comparison. The main fact of that is that Air France - KLM group is also a group merge. In comparison of employee numbers, that two companies are head to head to have effective background and it is quite normal for that kind of merges.

\section{Occupancy Rate}

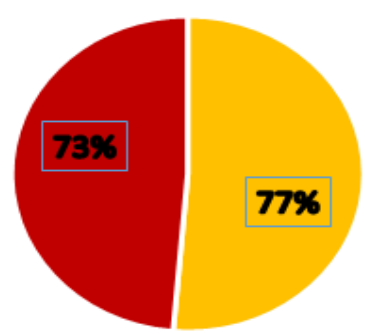

- Lufthansa Group = Turkish Airlines

\section{Occupancy Rate}

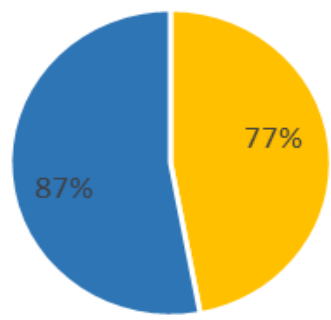

- Lufthansa Group - Air France

Fig. 4 Occupancy Rates [10][11]

Only head to head figure is Occupancy Rates, Figure 4. Lufthansa Group is $4 \%$ further when compared these numbers. But that $4 \%$ means a lot when compared the fleet sizes too. Lufthansa Group has two times bigger fleet and that $4 \%$ becomes even bigger and that difference is much bigger than double. Besides, Air France - KLM group has denser occupancy in their flights. It causes by their low rates of flights and low numbers of destinations. It cannot show us that they are better than these two companies under the light of other figures.

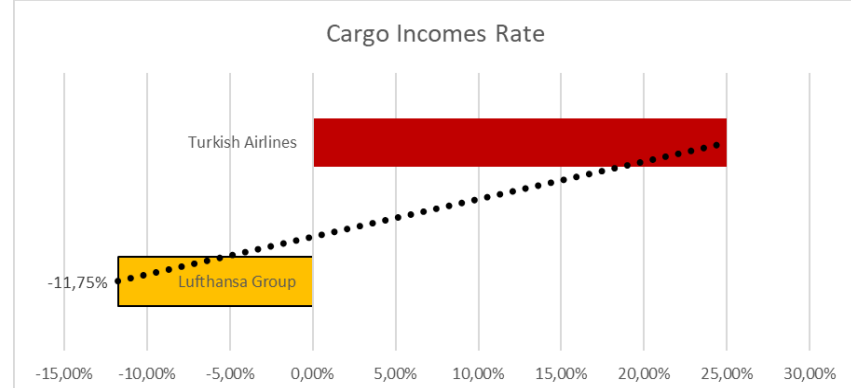

Fig. 5 Cargo Incomes Rates for Last Term [10][11]

Cargo provide section is competitive between two companies, and that massive gap from last terms data shows that Turkish Airlines is far step further than Lufthansa Group. The most significant fact to induce that big gap is position of Turkish Airlines again. And with customer services and passenger transportation, Turkish Airlines also works on cargo shipments. Their policies to connect different transportation modes to their hubs and Turkey's policy of being hub between 3 continents helps them to have that much development through cargo shipments. Lufthansa Group has minus rates of cargo incomes; it does not always show that they are losing money. Main policy of Lufthansa Group is purchasing the assets and that gap might reflect that investments. Also useful to mention, Lufthansa Group has an older fleet on their cargo section. It also provides advantage to Turkish Airlines for competition. For few next years, Turkish Airlines would not need to purchase new fleet, or loan, but Lufthansa Group will need it sooner or later. It means that gap would get bigger in few years.

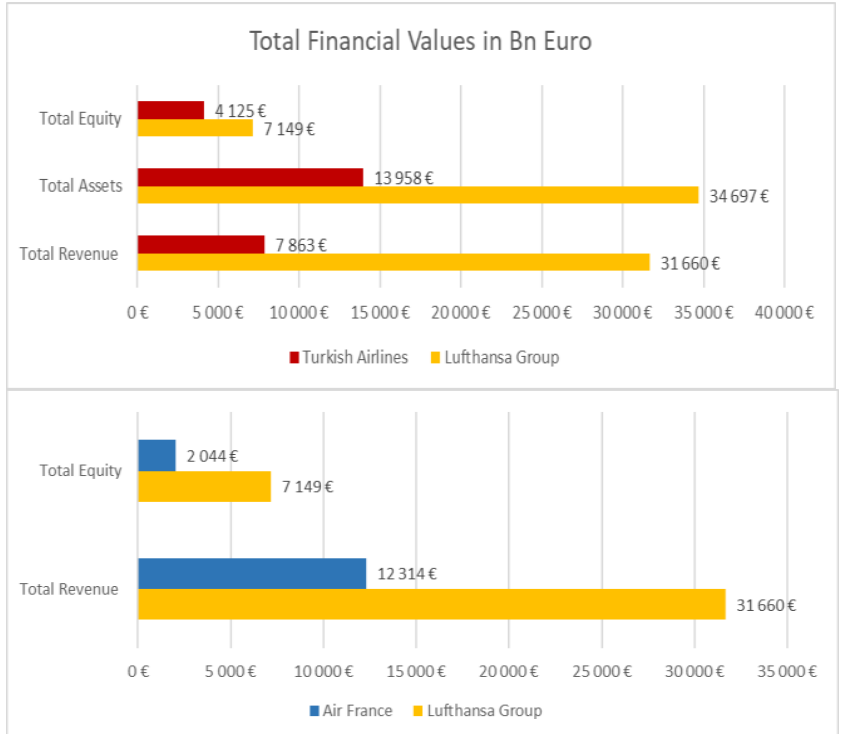

Fig. 6 Total Revenue - Assets - Equity [10][11]

Last figure of comparison and analysis shows the differences between equity, assets and revenue. Lufthansa Group is one step forward with all money facts and it is in their advantage to keep growing up. But better to mention, these data show whole Lufthansa Group. And if we look for Lufthansa alone data, we can see these two companies are head to head with that facts.[6]

Through comparison between Lufthansa Group and Air France - KLM Group, we can see great gaps in the way of Lufthansa Group's leadership. And with that last figure everything becomes even more clear: Lufthansa Group is the head of Europe air transportation market in related to comparison with Air France - KLM 
Group. But they share one of three shares of their just because of long-haul flights.

\section{DISCUSSION}

With many simple data and comparison, it is actually easy to find the situation and competition between that two titans of Europe air transportation. Even they have great powers to compete like KLM - Air France companionship, they can dominate the market and market shares through Europe. By those bunch of basic analysis, we can see current way of companies and further steps. [6]

Turkish Airlines try to become individual power in its area and they can try to shape the main service areas. In this purpose, they create new destinations, even with other companies and companion with alliance. It is a kind of win-win situation for them. And do they succeed? Yes, they do. It also feeds opponents but world is rounding with that way these days. [7]

Lufthansa Group has their own policy to grow and spread. It is quite obvious and so far, not surprisingly effective too. They provide more services in a specific area by holding the majority of shares of the market. Beyond that, they purchase the majority of share. They keep an eye on monopolization through Europe. Is it possible with these circumstances in Europe air transportation market? It is not quite possible. It can work until a point but you cannot see the end of the way or the top point. For many years ago it could work but now, Europe and world getting more service-required and single companies or partnerships wouldn't be enough to achieve it. In a single way it is impossible to get enough the requirements of Europe market but with others and win-win strategies its possible. The point is to play cards in the right way, like owning the specific share in market.

Air France - KLM Group also tries to have a share just with long-hauls. The partnership of the two small and consumed companies cannot be as effective as they wish while Lufthansa Group in market. They just can try to compete and hand just a small amount of shares but it would not push Lufthansa Group so hard. But if they decide to stand in that edged, they can keep the situation, it does not seem to that they can grow more just with that policies. Lufthansa Group becomes more and more powerful through Europe market and especially long-hauls to avoid a massive and one by one competition with Turkish Airlines. it will lead them to push on Air France - KLM partnership and it would make the business even harder for Air France - KLM Group. [8] [15]

\section{CONCLUSION}

In consideration of given values, specific data and comments above, for both companies (or group and partnerships) it is essential to trace current strategies for them to reach main purpose, which is to hold more share from market. Besides, having new strategies would enrich to spread both through their goals. Examining the numbers will show that they are more than that analysis and practice.

From the numbers that indicate Turkish Airlines has a lot destination point, and the leadership position of them, we can see that they have furthermore strategies beyond near Africa, Europe and Asia (table 1 - page 3). Turkish Airlines has 2 times more flights from Europe to world. These numbers include far Europe flights too. And it cannot be that easy to have that big numbers with all other competitors like KLM - Air France partnership and massive Lufthansa Group. Even against them, Turkish Airlines holds the much more flight numbers. It is caused by the alliance partnership and being hub strategies. Also from the same table, Turkish Airlines has the best numbers from Africa to world flights, which is 3 times more than closest opponent. And for top 3 companies, both of other 2 opponents are from Europe. It also shows us that Turkish Airlines dominates the African market too. It indicates that they have other strategies in Africa. Africa was the bare area for trade but now it is being developed. And that development in trade also generates new field of trade in Africa: transportation. Thus, eating the cream of cake becomes the share of Turkish Airlines. Because they are closer, they have know-how support and most significantly they have common history with many African countries. So on, spreading that starts with north Africa has a place in south Africa too. How north Africa was bare to have new fields of trade, south Africa is barer to have that fields. Thus, Turkish Airlines tries to spread to south area. Do they succeed? So far so good. And they still have more opportunity to get more spread. The question is, can they have a monopolization in Africa? It seems like it is not quite possible because of the African titans such as Qatar Airways, Emirates and so on. These companies seem like they gave up on Africa, maybe not totally but even they are not strong enough against Turkish Airlines, with numbers of course. It is more likely they focused on world air transportation market.

Current situation of Lufthansa Group points that their major strategy is being the hub and the main service provider of Europe. In order to be the head of Europe market, they keep their spreading policy and also creating new destinations especially overseas like America. With that new destinations and ongoing policies, they can be the main hub between Europe and America at least. In these field of competition, they have quite effective opponents like British Airways and KLM - Air France partnership. Also Delta Airlines try to get involved the transfer process from Great Britain and especially from London. Maybe it does no harm to Lufthansa Group but it may get Lufthansa Group affected. Their main policy also would not get harmed by, but a great share from market would divide. Either way Lufthansa Group still keep their position in Europe but according to figures they are losing their market share. As well as Turkish Airlines is on the way to create an effective hub, Lufthansa Group must prepare an effective precaution program.

- In the other hand, Air France - KLM partnership retain the small amount of market share in Europe air transportation market. Only reason of that is the also main goal of Air France - KLM group, long-haul flights. As we mentioned before, Air France KLM is aware of Lufthansa Group's power in Europe market. And one only way out to profit is focusing on long-hauls. During that strategy, they also head to African market. It is a bit dangerous for them just because other part of competition: Turkish Airlines. We mentioned about Turkish Airlines strategy and we all know that they are focusing on Africa market, especially South Africa. That's why it is dangerous to focus on Africa market for Air France - KLM. However, their strategy on America market might work. So far it works but sustainability comes with doubts.

\section{ACKNOWLEDGMENTS}

This paper is published as one of the scientific outputs of the project: „The research on virtual reality elements application: the significant improvement of simulator performance characteristics", ITMS: 26220220167“.

\section{BIBLIOGRAPHY}

1. Dursun, M. E., O'Connell, J. F., Lei, Z., \& Warnock-Smith, D. The transformation of a legacy carrier - A case study of turkish airlines. Journal of Air Transport Management, 40, (2014). 106118. 
2. Günerergin, M., Günay, G., Çelikdemir, F. D. Z., \& Saǧnak, M. Turkish airlines: Fast growing star of skies. Asian Case Research Journal, 18(1), (2014). 35-59.

3. Kilic, H. S., Zaim, S., \& Delen, D. Development of a hybrid methodology for ERP system selection: The case of turkish airlines. Decision Support Systems, 66, (2014).82-92.

4. Kazda, A., Badanik, B., Tomova, A., Laplace, I., \& Lenoir, N. (2013). Future airports development strategies. Komunikacie, 15(2), 19-24.

5. Lazar, T., Sedláčková, A. N., \& Bréda, R. Regression in personal air transport of passengers evolution at selected airport time series method. [Regresija u osobnom zračnom prijevozu putnika-razvoj metode vremenskih serija u odabranoj zračnoj luci] Nase More, 62, (2015). 228-232. 1

6. Szabo, S., Vittek, P., Kraus, J., Plos, V., Lališ, A., Štumper, M., \& Vajdová, I. Probabilistic model for airport runway safety areas. Transport Problems, 12(2), (2017). 89-97.

7. Kwasiborska, A., \& Stelmach, A. Analysis of airport traffic in the context of environmental throughput. Transport Problems, (2014). 9(1), 129-140.

8. Blašková M, Škultéty F. U.S. intra-industry trade in air transport services: Measurement and results. Transp Probl 2015;10(2):15-22.

9. Turkish Airlines Investor web page profile. Source: http://investor.turkishairlines.com/tr/mali-veriler/sunumlar/1/2017

10. Air France-KLM First half financial report January-June 2017 Source http://www.airfranceklm.com/sites/default/files/publications/afkl_ rfs_2017_en_28072017.pdf

11. Lufhansa Group, Annual Report 2016 . Source: https://investorrelations.lufthansagroup.com/fileadmin/downloads/en/financialreports/annual-reports/LH-AR-2016-e.pdf

12. Križanová, A. et all. International environment analysis - basic assumption for effective international marketing in globalized economy, Autobusy : technika, eksploatacja, systemy transportowe. - ISSN 1509-5878. nr. 6 (2016)

13. Tomová, A., Materna,M.: Long-haul low-cost air services: revealing key competitive features of airline within airline strategy
Ekonomiczne problemy usług : dawne Zeszyty Naukowe Universytetu Szczecińskiego. - ISSN 1896-382X. - Nr. 124 (2016)

14. Badanik, B., Kandera, B., Červínka, M.: Moving cargo by air: in a safe way, INAIR 2012. - Žilina: Žilinská univerzita, 2012. ISBN 978-80-554-0574-2.

15. Tomova, A.: Economics of air navigation services, Žilina : Žilinská univerzita, 2014. - ISBN 978-80-554-0905-4

16. Žáčik, N. Novák, A. Traditional promotion activities, TTS Technika Transportu Szynowego, 2016, R. 23, nr 12, ISSN -12323829

\section{Brief Economic Analysis and Comparison of Turkish Airlines, Lufthansa Group, Air France - KLM}

The paper described brief economic analysis and comparison of Turkish Airlines, Lufthansa Group and Air France - KLM. Throughout the economic and commercial development and with disappearance of boundaries between countries is rapidly changing air transport. The transportation and logistics investments and competition between companies and states rapidly increased. Thus, transportation modes developed and changed rapidly as a natural response to development itself. In the paper, we will practice the comparison of two major companies of European Air Freight: Turkish Airlines and Lufthansa.

Autorzy:

MSc. Muhammed Furkan Kuran - Istanbul University / Faculty of Logistics and Transportation, 34320 Avcilar , Istanbul, Turkey. e-mail: furkankuran@hotmail.com

prof. Ing.. Andrej Novak, PhD - Zilinská univerzita v Žiline University of Žilina , Univerzitná 8215/1, 01026 Žilina, Slovakia, e-mail: Andrej.Novak@fpedas.uniza.sk

JEL: L93 DOI: 10.24136/atest.2018.196

Data zgłoszenia: 2018.05.25 Data akceptacji: 2018.06.15 